\title{
INDIA-PAKISTAN BILATERAL NUCLEAR ARMS CONTROL SYSTEM AND ITS PRACTICAL IMPLEMENTATION: A PAKISTANI VIEW
}

\author{
A. Yu. Pavlov \\ Saint Petersburg State University \\ Saint Petersburg, Russia \\ M. Kamyssov \\ Saint Petersburg State University \\ Saint Petersburg, Russia
}

\begin{abstract}
Traditionally, the term nuclear arms control is strongly associated with the Nuclear Nonproliferation Treaty or Russian-American bilateral agreements. Besides the US-Russia regime, there is at least one more interesting case in the world, which certainly deserves attention - a specific case of India-Pakistan relations in this field. These two countries had to interact in a very peculiar regional and bilateral context, and thus they have formulated their specific understanding of basic concepts of nuclear arms control. The world's current situation is developing towards revising nuclear arms control mechanisms and possible expansion of multilateral formats of arms control negotiations. Although these states possess nuclear weapons, they are outside the current nuclear non-proliferation regime. Yet, Pakistan and India could be potentially involved in the extended format of the debate. So, the understanding of their bilateral practices addressing nuclear arms control mechanisms is necessary for the initiation of a constructive discussion with them. The measures taken by the two Governments are not regarded as arms control in the classical Western approach to research in this field. Still, the authors suppose reviewing the Pakistani attempts to establish the peculiar South Asian bilateral nuclear arms control between India and Pakistan.
\end{abstract}

Keywords: Nuclear arms control, Pakistan, India, non-proliferation, bilateral relations.

For citation: Pavlov, A. Yu. and Kamyssov, M. (2021), "India-Pakistan Bilateral Nuclear Arms Control System and Its Practical Implementation: a Pakistani View”, Koinon, vol. 2, no. 2, pp. 224-236. DOI: 10.15826/koinon.2021.02.2.024 


\title{
ДВУСТОРОННЯЯ СИСТЕМА КОНТРОЛЯ НАД ЯДЕРНЫМИ ВООРУЖЕНИЯМИ МЕЖДУ ИНДИЕЙ И ПАКИСТАНОМ И ЕЕ ПРАКТИЧЕСКОЕ ПРИМЕНЕНИЕ: ВЗГЛЯД ПАКИСТАНА
}

\author{
А. Ю. Павлов \\ Санкт-Петербургский государственный университет \\ Санкт-Петербург, Россия \\ М. Камысов \\ Санкт-Петербургский государственный университет \\ Санкт-Петербург, Россия
}

\begin{abstract}
Аннотация: Традиционно термин «контроль над ядерными вооружениями» прочно ассоциируется с Договором о нераспространении ядерного оружия или двусторонними российско-американскими соглашениями. Однако, помимо американо-российского режима, в мире существует по меньшей мере еще один прецедент, безусловно заслуживающий внимания - индийскопакистанские отношения в этой сфере. Этим двум странам приходится взаимодействовать в своеобразном региональном и двустороннем контекстах, что оказывает влияние на формулирование собственного понимания ключевых концепций контроля над ядерными вооружениями. Текущая ситуация в мире развивается в направлении пересмотра механизмов контроля над ядерными вооружениями и возможного расширения диалога посредством использования многосторонних форматов. Пакистан и Индия, как государства, обладающие ядерным оружием, но находящиеся вне нынешнего режима ядерного нераспространения, могли бы быть вовлечены в расширенный формат обсуждения. Таким образом, понимание особенностей их двусторонних практик необходимо для начала конструктивного диалога с ними. Несмотря на то что меры, принимаемые правительствами двух стран, не рассматриваются как контроль над вооружениями с точки зрения классического западного подхода к исследованиям в данной области, эта статья предполагает обзор деятельности Пакистана в установлении двусторонней системы контроля над ядерными вооружениями в Южной Азии.
\end{abstract}

Ключевые слова: контроль над ядерными вооружениями, Пакистан, Индия, нераспространение, двусторонние отношения.

Для цитирования: Pavlov A. Yu., Kamyssov M. India-Pakistan Bilateral Nuclear Arms Control System and Its Practical Implementation: a Pakistani view // Koinon. 2021. T. 2. № 2. C. 224-236. DOI: 10.15826/koinon.2021.02.2.024 
The article presents a Pakistani view on the bilateral nuclear arms control system within its relations with India. The view is based on the opinion of Pakistani experts in the domain. However, the specific feature of the examined field of studies in Pakistani is that the expert community has strong ties with the decision-makers and C2 institutions that represent either retired or active military officers or officials, deeply involved in the process. Thus, the view seems to be consolidated, but due to the ability of experts to make statements in a personal capacity, there is an opportunity to have room for a discussion.

Relations between India and Pakistan are pregnant with multiple problems that have been gradually developing since their independence in 1947. The conflicting nature of the bilateral relationship provoked three full-scale wars over Jammu and Kashmir and numerous border conflicts of various intensity. But the year 1974 became a benchmark date. That year a new nuclear power had emerged in South Asia when India tested a nuclear device for the first time. It was the first case in the NPT regime history, that a state, which refused to sign, ratify and obey the treaty, conducted a nuclear test. Although the nuclear explosive device was not a weapon, and the test was declared peaceful-purpose, it influenced regional security climate and severely affected regional players' national security, first and foremost - that of Pakistan. The vivid discussions began in Pakistan and the words of Pakistan then-prime minister $Z$. Bhutto: if India acquires nuclear status, Pakistan will have to follow suit even if it entails eating grass', got a chance to become a reality [Wolpert 1983]. Pakistan decided to go nuclear.

Twenty-five years later, in May 1998, the countries reached the point of no return, when both nations decided to demonstrate their nuclear capabilities by conducting weapons tests. It served as the ground for revising the policies that countries were pursuing to ensure national security, also providing a new opportunity for dialogue. Relations in this area have many features dictated by the unique context of development since both countries have developed their nuclear weapons programs and their doctrines in their unique ways.

Nowadays, the nuclear non-proliferation regime is moving towards a crucial arms control mechanisms revision. More and more talks address the possible expansion of the arms control negotiations formats by multilateral dialogue. Thus, both India and Pakistan represent a definite point of interest as states possessing nuclear weapons but adhering to resistance to 'nuclear apartheid' staying aside from the existing regime. So, the understanding of their bilateral nuclear arms control mechanisms is necessary for launching a constructive dialogue.

India and Pakistan develop their nuclear forces and strategies in the situation of mutual hostility and distrust. That forced them to try to increase their nuclear capabilities constantly. As well as the absence of a full-fledged dialogue in the field, this is determined by the fact that, despite a long history, the military nuclear programs of both countries are only forming. And one can compare it with the uncontrolled 
development of nuclear technologies in the USA and the USSR in the 40s-60s of the twentieth century [Khan Z. 2013].

These factors cause concerns not only in the region where both nations operate. They also attract the attention of experts worldwide, including Russia. Russian experts such as Alexey Arbatov, Vladimir Sotnikov and others made attempts to raise the awareness of the problems discussing the possible ways to reduce nuclear risks in the region [Ядерное противостояние 2005]. Nuclear doctrines of both states of the South Asian dyad also attract the attention of international experts [Сотников 2020; Perkovich 1999]. However, this article is mostly going to rely on South Asian literature.

At the current stage, the following factors define the context of relations between India and Pakistan in the nuclear domain:

- Common border with unresolved territorial disputes;

- Common border with China, which is also a nuclear power;

- Significant disproportion in size, population, economic and conventional military capabilities;

- Technological development misbalance in terms of early warning, space and ballistic missile defense programs;

- Strong desire to preserve and improve second-strike capabilities;

- The peculiar system of values and national risk-taking temper;

- Lack of formal dialogue, when contacts between the counterparts are represented, by large, by track 2 and 1,5 diplomacies.

The constant rivalry and conflicts between the two nations taught them to be cautious, so such a sensitive field as nuclear arms control could not remain unattended. The first attempt to reach an agreement occurred in 1988. That year the parties signed an agreement on the prohibition of attack against nuclear installations and facilities. The agreement established a common understanding of the meaning of the terms nuclear installations and facilities and prescribed to inform each other annually about the coordinates of their A-bomb facilities [Treaty on the Prohibition of Attack 1988]. Pakistan initiated these negotiations due to its deep concerns about the possible attack on its nuclear plants, as it happened when the Israeli attacked the Osirak nuclear reactor in Iraq in 1981 [Khan F. 2012]. India, in its turn, was concerned about the vulnerability of its nuclear facilities after F-16 jets were supplied to Pakistan by the USA [Khan F. 2010]. The agreement granted both countries some kind of assurance against a surprise attack on the nuclear facilities or attacks on them in case of war [French 2019].

The next and the largest in terms of significance attempt took place in February 1999. By that moment, both countries openly demonstrated their nuclear capabilities and started to reshape their security policies incorporating atomic weapons. The Lahore Declaration accompanied by the Memorandum of Understanding became the first step of rapprochement, which became possible thanks to Indian 
and Pakistani prime ministers' efforts, both of whom represented democratically elected leaders, A. Vajpayee and N. Sharif, respectively. The declaration became the first formal document, which directly addressed the issue of Indian-Pakistani nuclear arms control. The states agreed to:

Intensify their efforts to resolve security issues, first and foremost the issue of Jammu and Kashmir;

- Intensify their bilateral dialogue;

- Take measures to reduce nuclear risks;

- To discuss concepts and confidence-building measures within nuclear and conventional domains to prevent conflicts;

- To combat terrorism [The Lahore Declaration 1999].

The memorandum's text reinforced the provisions of the declaration but did not have a legally binding character. Thus, it became a kind of a list of recommendations which India and Pakistan agreed to follow. The text of the memorandum supposed that India and Pakistan shall:

- Establish bilateral consultation groups, discussing conventional and nuclear weapons-related issues;

- Establish a system of ballistic missile flight tests notification, having a bilateral agreement as a foundation;

- Establish measures, reducing nuclear risks through notifications and information exchange;

- Sustain their unilateral moratoriums on the nuclear tests, unless the supreme interests of the countries are not jeopardized;

- Establish and maintain Confidence Building Measures [Memorandum of Understanding 1999].

This initial dialogue could become a good foundation for further improvements in regional stability. Still, the instability of the Pakistani political system and disagreement between Pakistani prime minister N. Sharif and Chief of army staff and Chairman Joint Chiefs P. Musharraf provoked the conflict known as Kargil War in May 1999. This clash significantly undermined Indo-Pakistani relations (official Islamabad denied its participation in the conflict). Later General Musharraf organized a coup d'état overthrowing N. Sharif. The new government did not express the will to deepen the dialogue with India in the nuclear domain, thus leading the bilateral dialogue to an impasse. Since then, no significant efforts such as the Lahore declaration have been made to regulate these relations on the state level.

The lack of dialogue between the countries determined their further interaction, represented primarily by the principle of action-reaction. The two countries are constantly monitoring each other activities. Being in the 'fog of war' they try to understand the opposer's intentions, not always successfully.

Doctrinal problems represent one of the most significant issues for the two countries relations. Since the acquisition of nuclear weapons, it has become necessary to 
integrate them into general national military doctrines: to define the role of atomic weapons, their place in national strategies; to construct a system of command and control; to determine the conditions of nuclear weapons use, and other significant aspects. India demonstrated a draft military nuclear doctrine in 1999 and then updated it in 2003, while its counterpart still has not presented the proposition in a documented form for several reasons.

One of the reasons might be Pakistan's intention to preserve a high level of ambiguity in its nuclear strategy making its nuclear deterrence more credible to counterbalance its inferiority in conventional forces. Pakistan does not establish a clear nuclear threshold to deny the opponent the opportunity for a potential limited conventional or sub-conventional war. At the same time, to be credible in its deterrence, the Pakistani high-ranked officials and militaries make official and unofficial statements, which helps define the basic structure of the nuclear doctrine. The domestic and international political turbulence in the late 1990s - early 2000s also played an important role. According to some sources, the nuclear doctrine was ready to be presented in winter 1999. Unfortunately, the conflict between India and Pakistan in Kargil forced the government to postpone it, thus avoiding further escalation. After that, in August the same year, India presented its Draft Nuclear Doctrine and Islamabad decide not to show the Pakistani one not to be associated with tit for tat approach towards India. The following updated version of doctrine was ready to be publicly presented in 2001, but the 9/11 event again created an unfavourable context for its announcement. The disclosure of Abdul Qadir Khan's nuclear technology proliferation network, the ongoing war in Afghanistan, and internal political fluctuations were the main reasons for keeping the nuclear doctrine secret later. However, deliberate ambiguity is considered now the most efficient option to ensure deterrence [Salik 2016].

Another issue is that the two countries did not develop a shared system of terms and concepts that could facilitate the dialogue and the arms control process itself. Although both countries declared their adherence to the principle of minimum credible deterrence, both parameters, "minimal" and "credible", are not clearly defined by either party, adding to the existing ambiguity. The Pakistani perception is easierunderstandable, and Pakistan without nuclear weapons cannot counterbalance its competitor's superiority in conventional weapons. The Indian position raises more questions. India confronts two nuclear-weapon states, Pakistan and China. It further complicates applying the concept of minimum credible deterrence. The weapons available to India are not "minimal" regarding Pakistan, and "credible" enough regarding China, which deepens the distrust, giving Pakistan reasons to claim that India violates the principles declared by the doctrine [Sultan 2018].

The lack of uniformity in the classification of nuclear weapons also introduces specific difficulties in relations. The entire atomic potential of India, following the existing discourse, is considered strategic and aimed exclusively at deterring 
a potential adversary. And the principle of 'no first use' reflected in the doctrine dictates it. Due to the uncertainty of its proposition, Pakistan is silent about the possibility of using nuclear weapons first. However, it quite openly classifies the available arsenal as strategic and tactical, envisaging the option to use it as a means of warfare in case of extremal need [Lavoy 2008].

The issue of the "urgent need" has particular importance. The Indian Proactive Operations Doctrine, also known as the Cold Start Doctrine, is one of the main issues in Indo-Pakistani strategic relations. This doctrine supposes the establishment and deployment of eight mobile groups capable of being used in a limited war to penetrate Pakistani territory and destroy the objects of its nuclear infrastructure in case of war. The Indian think tanks designed that strategy to deprive Pakistan of the ability to exercise atomic retaliation. It is a violation of the 1988 non-aggression agreement, in Pakistan's opinion. The doctrine was kept secret by India for a long time, and officials completely denied its existence until 2017, when the Chief of Staff of the Army, General B. Rawat, admitted its actual presence [Unnithan 2017]. After that, Pakistan started to accuse India of provocation and a desire to take advantage of conventional superiority to unleash a limited war. As a matter of response in this area, Pakistan has developed a tactical short-range ballistic missile Hatf IX (Nasr) capable of carrying a nuclear warhead with a yield of $0.5-5$ kilotons. The missile is presented as a counterweight that can be used on the battlefield to protect Pakistani nuclear facilities [Shukla 2017]. Despite the declared tactical character of the missile, it contributes to the credibility of Pakistani deterrence, preventing India from a conventional attack.

India defines the 'No first use' as a fundamental of its nuclear posture while having 1,237 million troops versus the Pakistani army of 560 thousand people. It presents significant conventional superiority, allowing one to rely on it in case of conflict without using nuclear weapons [The Military Balance 2020]. This is why Pakistan tends to rely on its nuclear forces, reserving the possibility to use its nuclear weapons first. Nevertheless, it is necessary to take into account, that under its nuclear doctrine, released in 2003 India adheres to the massive retaliation strategy, planning to use all strategic nuclear forces in case of an atomic, chemical or biological attack against Indian troops inside or outside India [Government of India, 2003]. However, this raises skepticism on the part of Pakistan, which views a massive retaliation scenario as unlikely in response to the limited use of tactical nuclear weapons. And it also undermines the "credibility" of Indian deterrence.

The above-described case is a good illustration of the action-reaction principle of India-Pakistani relations in the nuclear arms control domain, given the absence of a dialogue between the governments. Strategists and intelligence services of both countries permanently monitor each other initiatives and activities to respond effectively to the new challenges without direct contact. However, it is not the only possible way to interact in the field, even in the existing circumstance of high-degree 
mutual distrust. One of the alternatives is implementing some confidence-building measures to decrease mistrust and create a favourable environment for further cooperation.

Some might define confidence-building measures (CBM) as 'planned procedures to prevent hostilities, to avert escalation, to reduce military tension, and to build mutual trust between countries' [French 2019]. Throughout the 70-year-long history of their relations, India and Pakistan had some experience of confidence-building measures development. The aftermath of the third Indo-Pakistani war of 1971 was a hotline between Indian and Pakistani directors-general of military operations as a backchannel for further crisis resolution and the Simla Accord, containing the provision of non-interference in one another affairs and non-use of force [French 2019]. The 1988 Agreement on the Non-Attack of Nuclear Facilities is also considered a military CBM, which opened the way to some non-military measures, such as the Cultural Cooperation Agreement and the establishment of the crisis hotline between Indian and Pakistani prime ministers.

After the 1998 nuclear tests, the two countries realized the necessity to negotiate, but still, the level of distrust was too high, which could not allow full-scale cooperation. The Lahore Declaration and Memorandum of Understanding (MOU) were designed to set up a ground for more concrete measures. Even though the Kargil War significantly undermined the prospects for negotiations and the coup d'état in Pakistan, the two countries understood the need to bring more clarity to the general atmosphere of uncertainty in the nuclear weapons-related field.

The first significant measure in the nuclear domain designed to prevent the fading of the Lahore agreement was the agreement on pre-notification of ballistic missile flight tests, which included a direct reference to MOU in its preamble [Memorandum of Understanding 1999]. The agreement aims to ease the tension in the border areas: to 'prevent misunderstandings and misinterpretations and promote a stable environment of peace and security between the two countries, by early notifications about flight tests of land, sea, surface-to-surface ballistic missiles. The agreements also prescribed the territories where the tests can take place and established limitations on trajectories of the ballistic missiles so that they would not cross the borderline or the Control Line established in Kashmir [Agreement on pre-notification 2005].

This agreement yelped to decrease the probability of escalation in a conflict that can be caused by a misperception of a missile flight test as an attack by any party. Its significance is crucial due to the geographical proximity of the parties.

The 2007 Agreement on Reducing the Risk from Accidents Relating to Nuclear Weapons became the next one and the last attempt to reach an agreement in the nuclear arms control domain. Again, its preamble refers to the spirit of the 1999 MOU between the parties [Agreement on Reducing the Risk 2007]. The agreement was designed to encourage the parties to enhance nuclear security 
and safety on the related facilities to avoid situations, which could provoke radioactive catastrophe or other acts, able to cause an outbreak of nuclear war between the parties [Agreement on Reducing the Risk 2007]. It also envisaged the exchange of notifications through hotline links established between the Foreign Secretaries and Directors General of Military Operations and set up the procedure of consultations. The term was five years, with the opportunity to be extended for another five years, so it was renewed in 2012 and 2017.

It is possible to see that the described measures taken in the field do not restrict any development, production or deployment of nuclear weapons. Most of them are non-binding as there is no political will to limit somehow A-and-H-bombs. Thus, confidence-building measures first and foremost contribute to reducing the risk of war and establishing some additional communication channels. Unfortunately, no country uses them actively.

Pakistan tends to be more proactive in the field. There are several reasons for it. The main is a disparity in economic development. Pakistan tries not to be involved in an uncontrolled nuclear weapons arms race with India. Pakistan made various offers to India, ranging from a nuclear-weapons-free zone in South Asia to joint inspections and limitations of the certain technologies development and deployment of some weapons systems [FAS 1998].

One of the brightest initiatives was to create a so-called "Zero Missile Zone" to limit the missile race between India and Pakistan. The initiative included the prohibition of permanent deployment of ballistic missiles, establishing an effective system of notification about missile flight-tests and restricting the development and deployment of anti-ballistic systems [Jaspal 2005]. All these measures are supposed to reduce the pace of the arms race and respective spending. India accepted only one of these propositions - the system of notifications.

Another important concept that Pakistan has been trying to promote since October 1998 is the Strategic Restraint Regime (SRR), aimed at proportionate reduction in the armed forces and peaceful resolution of all lingering disputes between India and Pakistan. According to the initiative it was supposed that India would have approximately 100 nuclear warheads, so Pakistan would follow suit, possessing a matching number of warheads [Chaudhry 2016]. India rejected this proposal because its deterrence is directed not only against Pakistan but also China. Nowadays, these conditions are not acceptable to either party. However, Pakistan sometimes recalls the old initiative with corrections. Recently there was an attempt to apply the SRR initiative to possible MIRV flight testing [Khan Z. 2019].

Summing up, it is possible to say that Indian-Pakistani relations represent a complex set of issues, with the flourishing atmosphere of mutual distrust, lacking the official dialogue between Indian and Pakistani governments. For more than two decades after the states acquired nuclear weapons, they still lack a shared conceptual basis and common language in the field, making timid attempts after a failed 
rapprochement in 1999. The efforts taken by Pakistan in the area of nuclear arms control can be conditionally divided into three groups:

Fundamental initiatives aimed at laying a fundament of a future dialogue Lahore declaration and MOU;

Propositions on confidence-building measures, designed to reduce the tension in relations with India and decrease nuclear risks - Agreement of pre-notification of ballistic missile flight tests, Agreement on Reducing the Risk from Accidents Relating to Nuclear Weapons;

Initiatives, deriving from strategic considerations, aimed at bringing India to negotiations on restraints, limitations and prohibitions of nuclear weapons Strategic Restraint Regime, "Zero Missile Zone" Proposal, and so on.

The relations between India and Pakistan are complex. Still, they lack a crisis management experience, but the main achievements, reached by the sides by the current moment are the establishment of the backchannels for communication, adherence to the responsibilities of the reached agreements and gradual improvement of the strategic environment by confidence-building measures, which proved to be respected and extended after their expiration dates. Nevertheless, the steps taken are not enough to classify the existing relations between the two countries as an efficient arms control regime. But these measures altogether might be considered as a certain arms control system from the South Asian perspective.

\section{References}

Agreement between the Republic of India and the Islamic Republic of Pakistan on Pre-Notification of Flight Testing of Ballistic Missiles (Islamabad, 3 October) (2005), Ministry of External Affairs of the Republic of India, available at: http://mea.gov.in/Portal/LegalTreatiesDoc/PA05B0591.pdf (accessed 26 December 2020).

Agreement between the Republic of India and the Islamic Republic of Pakistan on Reducing the Risk from Accidents Relating to Nuclear Weapons (New Delhi, 21 February) (2007), Ministry of External Affairs of the Republic of India, available at: https://mea.gov.in/Portal/LegalTreatiesDoc/ PA07B0425.pdf (accessed 26 December 2020).

Agreement on the Prohibition of Attack Against Nuclear Installations and Facilities between the Republic of India and the Islamic Republic of Pakistan (Islamabad, 31 December) (1988), Ministry of External Affairs of the Republic of India, available at: https://mea.gov.in/Portal/LegalTreatiesDoc/ PAB1232.pdf (accessed 26 December 2020).

Arbatov, A. and Chufrin, G. (2005), Yadernoe protivostoyanie v Yuzhnoi Azii [Nuclear confrontation in South Asia], Carnegie Moscow Center, Moscow, available at: https://carnegieendowment.org/ files/9328arbatov21.pdf (accessed 26 December 2020) (in Russian).

Chaudhry, S. (2016), “Strategic Restraint”, The News International, 11 March, available at: https://www. thenews.com.pk/print/104353-Strategicrestraint (accessed 27 December 2020).

French, R. W. (2019), “Constructing Cooperation: A New Approach to Confidence Building between India and Pakistan”, The Round Table, vol. 108, no. 2, pp. 121-144. DOI: 10.1080/00358533.2019.1591767.

Jaspal, Z. N. (2005), “Arms Control: Risk Reduction Measures Between India and Pakistan”, SASSU Research Paper, no. 1, June, 28 p., available at: https://www.files.ethz.ch/isn/99910/RP\%20No\%20 01.pdf (accessed 27 December 2020). 
Khan, F. H. (2010), "Prospects for Indian and Pakistani Arms Control and Confidence-Building Measures", Naval War College Review, vol. 63, no. 3, pp. 105-121, DOI: 10.1080/00358533.2019.1591767.

Khan, F. H. (2012), Eating grass: the making of the Pakistani bomb, Stanford University Press, Stanford, California, $550 \mathrm{p}$.

Khan, Z. (2013), “Pakistan's Policy of Arms Control and Disarmament: A Call for an Arms Control Regime in South Asia”, Defence Studies, vol. 13, no. 1, pp. 56-79. DOI: 10.1080/14702436.2013.774965.

Khan, Z. (2019), "Enact a restraint regime on MIRV Flight Testing in South Asia”, South Asian Voices, 06 June, available at: https://southasianvoices.org/enact-a-restraint-regime-on-mirv-flight-testingin-south-asia/ (accessed 27 December 2020).

Lavoy, P. (2008), “Islamabad's Nuclear Posture: Its Premises and Implementation”, in Sokolski, H. D. (ed.), Pakistan's Nuclear Future: Worries Beyond War, Strategic Studies Institute, Carlisle, PA, pp. 129-165.

Memorandum of Understanding (1999), Ministry of External Affairs of the Republic of India, available at: https://peacemaker.un.org/sites/peacemaker.un.org/files/IN\%20PK_990221_Memorandum\%20 of\%20Understanding.pdf (accessed 25 December 2020).

"Pakistan Nuclear Weapons - A Chronology" (1998), Federation of American Scientists, 03 June, available at: https://fas.org/nuke/guide/pakistan/nuke/chron.htm (accessed 26 December 2020).

Perkovich, G. (1999), India's Nuclear Bomb: The Impact on Global Proliferation, University of California Press, Berkeley, Los Angeles, California, $654 \mathrm{p}$.

Salik, N. (2016), “Pakistan’s Evolving Nuclear Doctrine”, in Salik, N. (ed.), Nuclear Pakistan Seeking Security \& Stability, Center for International Strategic Studies, Islamabad, pp. 49-67.

Shukla, K. (2017), “Army Chief Says Military Must Prepare for Cold Start”, Business Standard, 14 January, available at: https://www.business-standard.com/article/current-affairs/army-chiefsays-military-must-prepare-for-cold-start-117011301174_1.html (accessed 25 December 2020).

Sotnikov, V. I. (2020), “Comparative analysis of India's and Pakistan's nuclear doctrines”, Eastern Analytics, no. 1, pp. 98-109 (in Russian). DOI: 10.31696/2227-5568-2020-01-098-109.

Sultan, A. (2018), “India's Nuclear Doctrine: A Case of Strategic Dissonance or Deliberate Ambiguity”, IPRI Journal, vol. 18, no. 2, pp. 26-52. DOI: 10.31945/iprij.180202.

“The Cabinet Committee on Security Reviews operationalization of India's Nuclear Doctrine" (2003), Government of the Republic of India. Ministry of external affairs of India, available at: https:// mea.gov.in/press-releases.htm?dtl/20131/The_Cabinet_Committee_on_Security_Reviews_perationalization_of_Indias_Nuclear_Doctrine+Report+of +National+Security+Advisory+Board +o n+Indian+Nuclear+Doctrine\#: : :text=The\%20Cabinet\%20Committee\%20on\%20Security\%20 (CCS)\%20met\%20today\%20to\%20review,be\%20shared\%20with\%20the\%20public (accessed 25 December 2020).

The International Institute for Strategic Studies (2020), The Military Balance, International Institute for Strategic Studies, London, 504 p.

The Lahore Declaration (Lahore, 2 February) (1999), Ministry of External Affairs of the Republic of India, available at: https://peacemaker.un.org/sites/peacemaker.un.org/files/IN\%20PK_990221_ The\%20Lahore\%20Declaration.pdf (accessed 25 December 2020).

Unnithan, S. (2017), “We will cross again”, India Today, 4 January, available at: https://www.indiatoday.in/magazine/interview/story/20170116-lt-general-bipin-rawat-surgical-strikes-indianarmy-985527-2017-01-04 (accessed 25 December 2020).

Wolpert, S. (1983), Zulfi Bhutto of Pakistan: His Life and Times, Oxford University Press, New York, $416 \mathrm{p}$.

\section{Список литературы}

Сотников 2020 - Сотников В. И. Сравнительный анализ ядерных доктрин Индии и Пакистана // Восточная аналитика. 2020. № 1. С. 98-109. DOI: 10.31696/2227-5568-2020-01-098-109.

KOINON $2021 \sim$ T. 2 № 2 
Ядерное противостояние 2005 - Ядерное противостояние в Южной Азии [Электронный ресурс]/ под ред. А. Арбатова, Г. Чуфрина. М. : Московский Центр Карнеги, 2005. URL: https:// carnegieendowment.org/files/9328arbatov21.pdf (дата обращения: 26.12.2020).

Agreement of pre-notification 2005 - Agreement between the Republic of India and the Islamic Republic of Pakistan on Pre-Notification of Flight Testing of Ballistic Missiles (Islamabad, 3 October 2005) [Electronic resource] // Ministry of External Affairs of the Republic of India. 2005. URL: http:// mea.gov.in/Portal/LegalTreatiesDoc/PA05B0591.pdf (access date: 26.12.2020).

Agreement on Reducing the Risk 2007 - Agreement between the Republic of India and the Islamic Republic of Pakistan on Reducing the Risk from Accidents Relating to Nuclear Weapons (New Delhi, 21 February 2007) [Electronic resource] // Ministry of External Affairs of the Republic of India. 2007. URL: https://mea.gov.in/Portal/LegalTreatiesDoc/PA07B0425.pdf (access date: 26.12.2020).

Agreement on the Prohibition of Attack 1988 - Agreement on the Prohibition of Attack Against Nuclear Installations and Facilities between the Republic of India and the Islamic Republic of Pakistan (Islamabad, 31 December 1988) [Electronic resource] // Ministry of External Affairs of the Republic of India. 1988. URL: https://mea.gov.in/Portal/LegalTreatiesDoc/PAB1232.pdf (access date: 26.12 .2020$)$.

Chaudhry 2016 - Chaudhry S. Strategic Restraint [Electronic resource] // The News International. 2016. 11 March. URL: https://www.thenews.com.pk/print/104353-Strategicrestraint (access date: 27.12.2020).

FAS 1998 - Pakistan Nuclear Weapons - A Chronology [Electronic resource] // FAS: Federation of American Scientists. 1998. 03 June. URL: https://fas.org/nuke/guide/pakistan/nuke/chron.htm (access date: 26.12.2020).

French 2019 - French R. W. Constructing Cooperation: A New Approach to Confidence Building between India and Pakistan // The Round Table. 2019. Vol. 108. No. 2. P. 121-144. DOI: 10.1080/00358533.2019.1591767.

Government of India 2003 - The Cabinet Committee on Security Reviews operationalization of India's Nuclear Doctrine [Electronic resource] // Government of the Republic of India. Ministry of external affairs of India. 2003. URL: https://mea.gov.in/press-releases.htm?dtl/20131/The_Cabinet_Committee_on_Security_Reviews_perationalization_of_Indias_Nuclear_Doctrine+Report+of + Nat ional+Security+Advisory+Board+on+Indian+Nuclear+Doctrine\#: : text=The\% 20Cabinet\% 20 Committee\%20on\%20Security\%20(CCS)\%20met\%20today\%20to\%20review,be\%20shared\%20 with\%20the\%20public (access date: 25.12.2020).

Jaspal 2005 - Jaspal Z. N. Arms Control: Risk Reduction Measures Between India and Pakistan [Electronic resource] // SASSU Research Paper. 2005. No. 1. June. 28 p. URL: https://www.files.ethz. ch/isn/99910/RP\%20No\%2001.pdf (access date: 27.12.2020).

Khan 2010 - Khan F. H. Prospects for Indian and Pakistani Arms Control and Confidence-Building Measures // Naval War College Review. 2010. Vol. 63. No. 3. P. 105-121. DOI: 10.1080/00358 533.2019.1591767.

Khan 2012 - Khan F. H. Eating grass: the making of the Pakistani bomb. Stanford : Stanford University Press, 2012. 550 p.

Khan 2013 - Khan Z. Pakistan's Policy of Arms Control and Disarmament: A Call for an Arms Control Regime in South Asia // Defence Studies. 2013. Vol. 13. No. 1. P. 56-79. DOI: 10.1080/14702436.2013.774965.

Khan 2019 - Khan Z. Enact a restraint regime on MIRV Flight-Testing in South Asia [Electronic resource] // South Asian Voices. 2019. 06 June. URL: https://southasianvoices.org/enact-a-restraintregime-on-mirv-flight-testing-in-south-asia/ (access date: 27.12.2020).

Lavoy 2008 - Lavoy P. Islamabad's Nuclear Posture: Its Premises and Implementation // Pakistan's Nuclear Future: Worries Beyond War / ed. by H. D. Sokolski. Carlisle, PA : Strategic Studies Institute, 2008. P. 129-165.

Memorandum of Understanding 1999 - Memorandum of Understanding (Lahore, 2 February 1999) [Electronic resource] // Ministry of External Affairs of the Republic of India. 1999. URL: https://

$$
\text { KOINON } 2021 \text { Vol. } 2 \text { № } 2
$$


peacemaker.un.org/sites/peacemaker.un.org/files/IN\%20PK_990221_Memorandum\%20of\%20 Understanding.pdf (access date: 25.12.2020).

Perkovich 1999 - Perkovich G. India's Nuclear Bomb: The Impact on Global Proliferation. Berkeley : Los Angeles, California : University of California Press, 1999. 654 p.

Salik 2016 - Salik N. Pakistan's Evolving Nuclear Doctrine // Nuclear Pakistan Seeking Security \& Stability / ed. by N. Salik. Islamabad : Center for International Strategic Studies, 2016. P. 49-67.

Shukla 2017 - Shukla A. Army Chief Says Military Must Prepare for Cold Start [Electronic resource] // Business Standard. 2017. 14 January. URL: https://www.business-standard.com/article/currentaffairs/army-chief-says-military-must-prepare-for-cold-start-117011301174_1.html (access date: 25.12.2020).

Sultan 2018 - Sultan A. India's Nuclear Doctrine: A Case of Strategic Dissonance or Deliberate Ambiguity // IPRI Journal. Vol. 18. No. 2. P. 26-52. DOI: 10.31945/iprij.180202.

The Lahore Declaration 1999 - The Lahore Declaration (Lahore, 2 February 1999) [Electronic resource] // Ministry of External Affairs of the Republic of India. 1999. URL: https://peacemaker. un.org/sites/peacemaker.un.org/files/IN\%20PK_990221_The\%20Lahore\%20Declaration.pdf (access date: 25.12.2020).

The Military Balance 2020 - The Military Balance. London : International Institute for Strategic Studies, 2020. $504 \mathrm{p}$.

Unnithan 2017 - Unnithan S. 'We will cross again' [Electronic resource] // India Today. 2017. 4 January. URL: https://www.indiatoday.in/magazine/interview/story/20170116-lt-general-bipin-rawatsurgical-strikes-indian-army-985527-2017-01-04 (access date: 25.12.2020).

Wolpert 1983 - Wolpert S. Zulfi Bhutto of Pakistan: His Life and Times. New York : Oxford University Press, 1983. 416 p.

Рукопись поступила в редакцию / Received: 23.03.2021

Принята к публикации / Accepted: 23.07.2021

\section{Информация об авторах}

Павлов Андрей Юрьевич

доктор исторических наук, профессор

Санкт-Петербургский государственный

университет

190121, Россия, Санкт-Петербург, ул.

Галерная, 58-60

E-mail: apavlov@inbox.ru

Авторский ORCID: 0000-0002-1095-4022

Камысов Максат

магистр международных отношений

Санкт-Петербургский государственный университет

190121, Россия, Санкт-Петербург, ул.

Галерная, 58-60

E-mail: 19_05_maks@mail.ru

Авторский ORCID: 0000-0003-2411-0557

\section{Information about authors}

Pavlov, Andrei Yur'evich

D. Sci. (History), Professor

St.-Petersburg State University

58-60 Galernaya St., Saint Petersburg, 190121 Russia

E-mail: apavlov@inbox.ru

Author's ORCID: 0000-0002-1095-4022

Kamyssov, Maksat

Master's degree in International Relations

St.-Petersburg State University

58-60 Galernaya St., Saint Petersburg,

190121 Russia

E-mail: 19_05_maks@mail.ru

Author's ORCID: 0000-0003-2411-0557 